\title{
Extraction \& Processing Division: Activities and Updates
}

\author{
Adrian Deneys, Mark Schlesinger, Tom Battle, Boyd Davis, and Mike Free
}

\section{BACKGROUND}

The Extraction \& Processing Division (EPD), one of five TMS technical divisions, has more than 800 members, most of whom reside outside of the United States. The main focus of the EPD is the sustainable extraction and processing of minerals and metals from mined ores, concentrates, and recycled materials using pyrometallurgical, hydrometallurgical, and/or electrochemical processes. The technical, engineering, environmental, and economic principles of such processes are the focus of division activities.
The EPD also addresses further processing of non-ferrous metals such as copper, nickel, cobalt, precious metals, lead, zinc, and tin and their products by techniques such as refining, purification, alloying, solidification, thermomechanical treatment, and surface coating into finished and semifinished products.

The division utilizes six technical committees and a council of supporting positions to accomplish its objectives. The technical committees include Energy (joint with the Light Metals Division), Hydrometallurgy and Electrometallurgy, Materials
Characterization, Process Technology and Modeling (joint with the Materials Processing \& Manufacturing Division), Pyrometallurgy, and Recycling Recycling and Environmental Technologies (joint with the Light Metals Division).

\section{ANNUAL MEETING ACTIVITIES}

\section{Symposia}

In general the EPD seeks to support efforts brought forward by members that provide benefits to members. One of the primary areas of support for its

\begin{tabular}{|c|c|}
\hline \multicolumn{2}{|c|}{ Extraction \& Processing Division Sponsored Symposia } \\
\hline Symposium & Organizers \\
\hline 3rd International Symposium on High Temperature Metallurgical Processing & $\begin{array}{l}\text { Jiann-Yang Hwang, Tao Jiang, Patrick Masset, Onuralp Yucel, Rafael Padilla, } \\
\text { Guifeng Zhou }\end{array}$ \\
\hline Battery Recycling & Gregory K. Krumdick, Linda Gaines \\
\hline CFD Modeling and Simulation in Materials Processing & $\begin{array}{l}\text { Laurentiu Nastac, Lifeng Zhang, Brian G. Thomas, Adrian Sabau, Nagy El- } \\
\text { Kaddah, Adam C. Powell, Hervé Combeau }\end{array}$ \\
\hline Characterization of Minerals, Metals, and Materials & $\begin{array}{l}\text { Jiann-Yang Hwang, Sergio Montero, Chenguang Bai, John Carpenter, Donato } \\
\text { Firrao, Byoung-Gon Kim, Mingdong Cai }\end{array}$ \\
\hline Electrometallurgy 2012 & $\begin{array}{l}\text { Michael L. Free, Georges Houlachi, Antoine Allanore, Michael Moats, Edouard } \\
\text { Asselin, Shijie Wang, James Yurko }\end{array}$ \\
\hline Energy Technologies and Carbon Dioxide Management & $\begin{array}{l}\text { Maria Salazar-Villalpando, Neale R. Neelameggham, Donna P. Guillen, } \\
\text { Subodh Das, Ramana Reddy, Animesh Jha, Soobhankar Pati, Mark Jolly, } \\
\text { Lakshmanan Vaikuntam }\end{array}$ \\
\hline $\begin{array}{l}\text { International Smelting Technology Symposium (Incorporating the 6th Advances } \\
\text { in Sulfide Smelting Symposium) }\end{array}$ & Jerome P. Downey, Thomas P. Battle, Jesse White \\
\hline Materials Processing Fundamentals & Lifeng Zhang, Antoine Allanore, Cong Wang \\
\hline Materials Research in Microgravity & $\begin{array}{l}\text { Robert W. Hyers, Hani Henein, Valdis Bojarevics, James Patton Downey, } \\
\text { Douglas M. Matson, Achim Seidel, Daniela Voss }\end{array}$ \\
\hline Production, Recovery and Recycling of Rare Earth Metals & Lifeng Zhang, Joseph A. Pomykala, Oliver Gutfleisch \\
\hline Recycling General Sessions & Joseph A. Pomykala \\
\hline Solar Cell Silicon & Arjan Ciftja, Gabriella Tranell, Gregory J. Hildeman, Shadia Jamil Ikhmayies \\
\hline $\begin{array}{l}\text { T.T. Chen Honorary Symposium on Hydrometallurgy, Electrometallurgy and } \\
\text { Materials Characterization }\end{array}$ & Shijie Wang, J.E. Dutrizac, Michael Free, J.Y. Hwang, Daniel Kim \\
\hline
\end{tabular}


members is in organizing symposia. At the TMS 2012 Annual Meeting, the EPD sponsored 13 symposia consisting of 637 presentations.

Several symposia were held in conjunction with other TMS divisions and two were co-sponsored by other societies (The Metallurgy and Materials Society of the Canadian Institute of Mining, Metallurgy and Petroleum, and the South African Institute of Mining and Metallurgy). A summary of the recent symposia and organizers is given in Table I.

\section{Short Courses}

Several short courses were sponsored by the EPD to expand the industrial knowledge base of annual meeting attendees. Those courses, and their organizers, were:

- Electrowinning and Electrorefining of Copper and Zinc, by Mike Moats, Edouard Asselin, Georges Houlachi

- Process Energy Modeling Spreadsheets and Beyond, by Art Morris, David Robertson, and Eric Grimsey

- The Estimation of Slag
Properties, by Ken Mills

Two of the short courses (Electrowinning and Electrorefining, and Estimation of Slag Properties) were held in conjunction with topical symposia (viz. Elecrometallurgy 2012, and International Smelting Technology Symposium). Process Energy Modeling Spreadsheets and Beyond ran for its second time.

\section{Awards}

The EPD also sponsors several awards and scholarships each year. In 2012 these included:

- EPD Distinguished Lecturer: Theo Lehner of Boliden Mineral, Sweden

- EPD Distinguished Service Award: T.T. Chen of CANMETMMSL in Ottawa, Canada

- EPD Technology Award: Jim Hwang, Xiang Sun, and Xiaodi Huang of Michigan Tech, USA

- EPD Science Award: James Miller, Richard B. Diver, Eric N. Coker, Andrea Ambrosini, Daniel E. Dedrick, Mark D. Allendorf, Anthony H. McDaniel, Gary L. Kellogg,
Roy E. Hogan, Ken S. Chen, and Ellen B. Stechel, all from Sandia National Labs, and Nathan P. Siegel, Bucknell University

- EPD Young Leaders: John Carpenter of Los Alamos

National Lab and Pati Soobhankar of Metal Oxygen Separation Technologies Inc.

- EPD Scholarship: Ashley Carter of Montana Tech

At the TMS society level, Antoine Allanore and Jim Yurko received the 2012 TMS Vittorio DeNora Prize. Congratulations to all of the EPD award winners!

The EPD web page can be found on the TMS website ( $w w w . t m s . o r g)$, login required with your TMS membership number.

Adrian Deneys is business development manager at Praxair, San Ramon, CA; Mark Schlesinger is a professor of Metallurgical Engineering at Missouri University of Science and Technology, Rolla, MO; Tom Battle is senior metallurgist at Midrex Technologies, Pineville, NC; Boyd Davis is a principal of Kingston Process Metallurgy Inc., Kingston, ON, Canada; Mike Free is a professor of Metallurgical Engineering at the University of Utah, Salt Lake City, UT. All are members of the Extraction \& Processing Division Council. Contact the Division Chair, Deneys, at TMSCommitteeChair_epd@tms.org for more information.

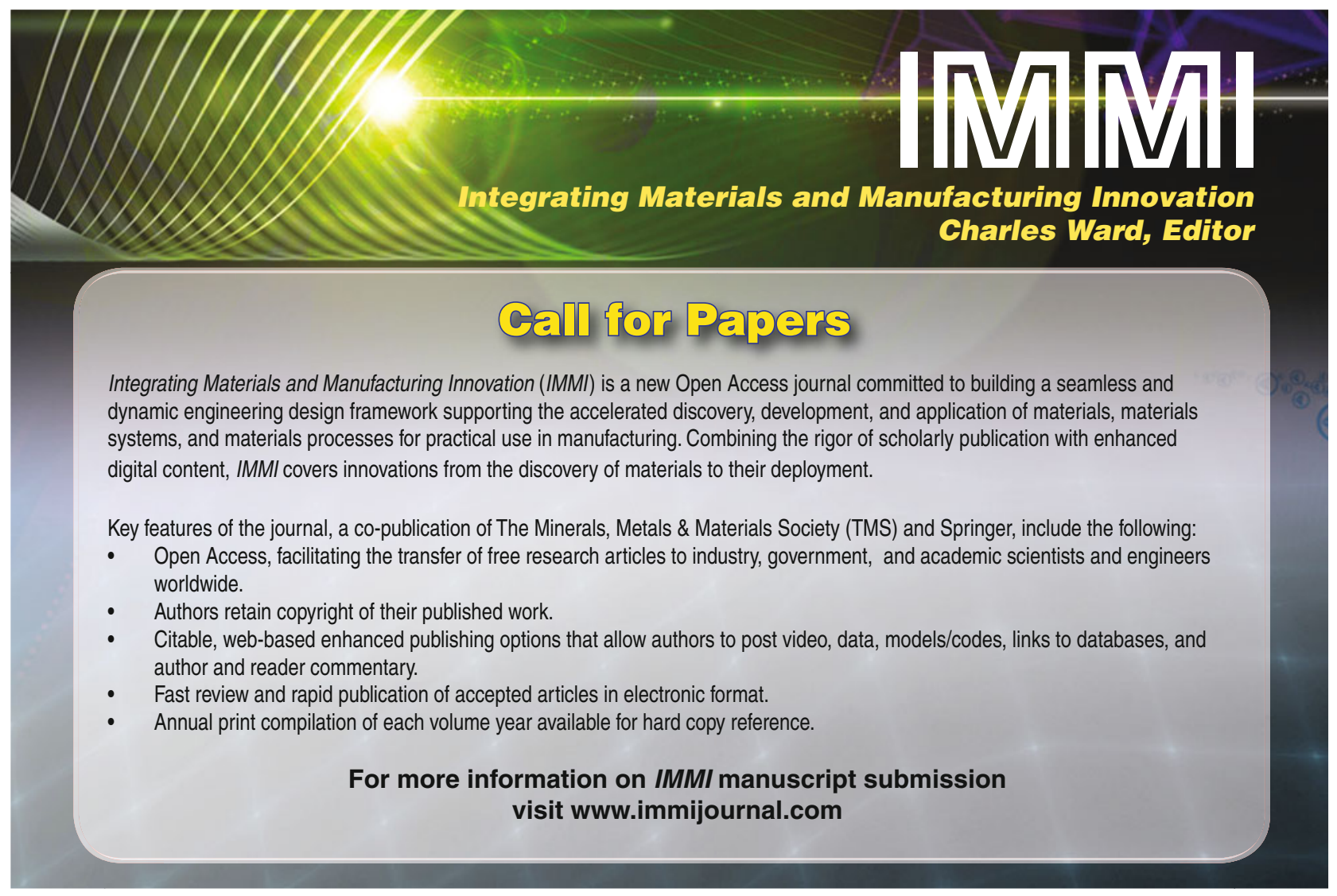

